\title{
Defining Heritage Science: A Consilience Pathway to Treasuring the Complexity of Inheritable Human Experiences through Historical Method, AI, and ML
}

\author{
Andrea Nanetti \\ Nanyang Technological University, Singapore \\ Correspondence should be addressed to Andrea Nanetti; nanetti.andrea@gmail.com
}

Received 29 July 2020; Revised 4 September 2020; Accepted 12 November 2020; Published 15 February 2021

Academic Editor: Shu-Heng Chen

Copyright (c) 2021 Andrea Nanetti. This is an open access article distributed under the Creative Commons Attribution License, which permits unrestricted use, distribution, and reproduction in any medium, provided the original work is properly cited.

\begin{abstract}
Societies have always used their heritage to remain resilient and to express their cultural identities. Today, all the still-available experiences accrued by human societies over time and across space are, in principle, essential in coping with the twenty-first century grand challenges of humanity (refer to the $17 \mathrm{UN}$ Sustainable Development Goals). Artificial intelligence and machine learning algorithms can assist the next generation of historians, heritage stakeholders, and decision-makers in (1) decoding unstructured knowledge and wisdom embedded in selected cultural artefacts and social rituals, (2) encoding data in machinereadable systems, (3) aggregating information according to the user's needs in real time, and (4) simulating the consequences of either erasing, neglecting, putting in latency, or preserving and sharing specific human experiences. What our global society needs is a multilingual and transcultural approach to decode-encode the treasure of human experience and transmit it to the next generation of world citizens. This approach can be the pathway to work on a new science of heritage, its ethics, and empathy.
\end{abstract}

\section{Introduction}

Since 1834, when Michael Faraday first talked about "heritage science" in his Royal Institution Christmas Lecture, this science of heritage has evolved from a disciplinary field focused on conservation sciences to its more recent opening as a domain to a broader range of research disciplines able to reflect better the breadth and depth required by our complex societies in dealing with its heritage (i.e., what may and should be sustainably inherited). The Singapore Heritage Science Conference series (2014-2016 (see Figure 1)) and the three-day event, Dancing over Ideas of Research (2018), provided a discussion forum on the role of heritage science in today's society (refer to [2, 3]). These two conferences confirmed that the multidisciplinary domain of heritage science focuses on recording, accessing, interpreting, conserving, and managing cultural heritage seen as the treasure of human experiences.

Today, heritage science considers the knowledge and values acquired in all relevant disciplines, from arts and humanities (e.g., philosophy, ethics, art and art history, economics, sociology, and anthropology) to fundamental sciences (e.g., chemistry, physics, mathematics, and biology), as well as to computer science, engineering, communication, and media studies. In particular, the 2nd Singapore Heritage Science Conference, "Heritage and the Creative Industries," held on 15-16 January 2015, wrestled with the tensions between age-old practices and our modern digital lifestyles. New media and non-conventional communications have risen as a challenge, creating new possibilities for cultural expressions and the advancement of learning. However, during the conference, there was a sense that we might be losing our humanity as lives become more and more digital, and the criteria of digital-data preservation are left to the neoliberal rules of the free market. In hearing experts-like Harold Thwaites in his keynote address-talk about past experiences and draw from them creative inspirations for the future, one could realise that human qualities like ethics, empathy, identity, and spirituality are bonding resources that serve to bind people together. In short, to be human is to 


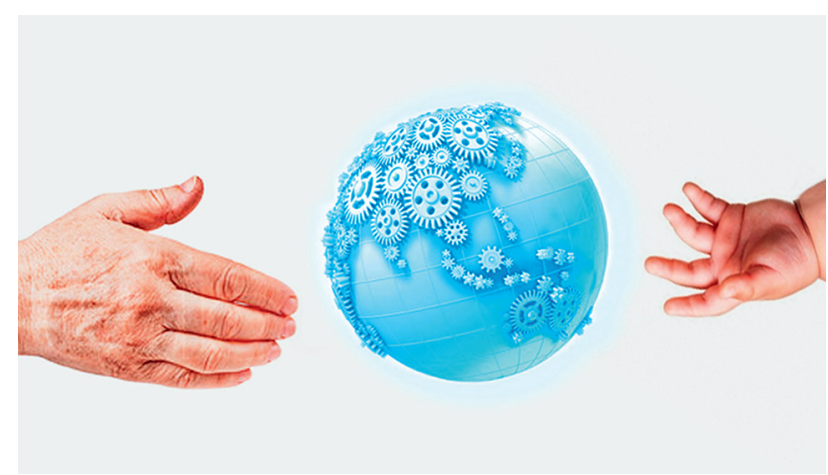

Figure 1: This rendering-realized in 2014 by Muhammad Mustajab Bin Mohamad, Higher Executive Officer (Publicity, outreach \& Alumni Relations) at the Nanyang Technological University School of Art, Design and Media-presents the 1st Singapore Heritage Science Conference concept as conceived by the conference chairs, Dr Andrea Nanetti and Dr Siew Ann Cheong. It shows an adult hand passing the world (identified as a complex mechanism with ASEAN at the centre) to a younger one. It is a good icon to summarise an approach to art, culture, and heritage in an AI perspective, where machine-generated algorithms may enhance the human transmission of data, information, knowledge, wisdom, and their relationships. This work was licensed under a Creative Commons Attribution-NonCommercial 4.0 International License (CC BY-NC 4.0) by Nanyang Technological University Singapore in 2014. For the Singapore Heritage Science Conference series (2014-2016, refer to www.paralimes.org for programmes, abstracts, and recordings of the presentations of the four conferences: 1st (January 2014) Heritage as a Complex System; 2nd (Jan. 2015) Heritage and the Creative Industries; Special edition (Nov. 2015) Exploring Maritime Heritage Dynamics; 3rd (Jan. 2016) The Treasure of Human Experiences. "Heritage poses the challenge of innovation in a new way: how does the new integrate with the old?" This was the key question raised by Helga Nowotny (founding member and former president of the European Research Council) in her keynote address at the 1st Singapore Heritage Science Conference on Heritage science as a complex system: The embarrassment of complexity: A phase of transition? The conference was organized and chaired by Andrea Nanetti and Siew Ann Cheong at Nanyang Technological University Singapore for the Complexity Program and the School of Art, Design and Media (6-7 January 2014, Figure 1). This event pioneered a new science of heritage as a state-of-the-art multidisciplinary domain able to investigate and discover integrated action plans and solutions in response to, and in anticipation of, the challenges arising from cultural heritage issues in society. Heritage is closely linked to the history and identity of communities. The complete video record of the conference is available from: http://www.paralimes.ntu.edu. sg/Pages/Home.aspx. The intellectual discussions facilitated by the Complexity Programme under the vibrant direction of Jan Vasbinder at Nanyang Technological University (NTU) Singapore between 2013 and 2018 have been extremely relevant in nurturing the idea of this new science of heritage and making the acquaintance with many renowned scholars from all-over the world, with whom I have discussed this idea and shared research projects.

be connected to other humans, to our environments, and, for some, to a cosmic significance. The conference presentations have been fully video recorded and are digitally available from http://www.paralimes.ntu.edu.sg/
NewsnEvents/HeritageandtheCreativeIndustry/Pages/Video\% 20Gallery.aspx.

This essay aims to discuss the shifting of the multidisciplinary domain of heritage science into an interdisciplinary algorithmic perspective, viz., able to take full advantage of computational tools and possibly avoid the biases of blind faith in technology and progress. Such a new science of heritage must sit on the shoulders of the giants in different research fields to overcome the dichotomy between the humanities and the sciences [4-8]. This process aims to lead to the interdisciplinary formalisation and integration of multidisciplinary bookish scholarship and practical experience of heritage (i.e., the inheritability of artefacts, oral traditions, scientific knowledge, social rituals, and other cultural practices that embody human experiences of the world and the human condition itself).

This new science of heritage should also find ways to raise awareness of the importance of immunisation against blind faith in technology and progress. Odysseas Elyt is epitomised this critical challenge in 1974: "I apologize for the easy symbolism, but the truth of our age 'amounts' to just this: an incredible technical progress strives to cure the ills caused to man by an incredible technical progress" (refer to [9]:35-36). Poets and essayists explored the human condition (including emotion, aspiration, conflict, and mortality) in search for this "vaccine" in relation to ways of living together without violence, for the salvation of humankind and possibly generate a new form of being. The inevitable "souffrance" of the living beings described in Giacomo Leopardi's garden-which with Emanuele Severino we can epitomise as "The game of mankind's destiny" in apparent anticipation of Nietzsche's thought-asks us if humans can withstand the immensity without losing themselves in its vertigo. In 1819, the 21-year-old Leopardi had already taken up the thought of Blaise Pascal (1623-1662): "The eternal silence of these infinite spaces frightens me" [10]. The context of this quotation from Pascal is the following: 205. When I consider the short duration of my life, swallowed up in the eternity before and after, the little space which I fill and even can see, engulfed in the infinite immensity of spaces of which I am ignorant and which know me not, I am frightened and am astonished at being here rather than there; for there is no reason why here rather than there, why now rather than then. Who has put me here? By whose order and direction have this place and time been allotted to me? Memoria hospitis unius diei praetereuntis [Bible, Sapientia/Book of Wisdom, 5:15 "the remembrance of a guest of one day that passeth by" (transl. Douay-Rheims)]. 206. The eternal silence of these infinite spaces frightens me. 207. How many kingdoms know us not! 208. Why is my knowledge limited? Why my stature? Why my life to one hundred years rather than to a thousand? What reason has nature had for giving me such, and for choosing this number rather than another in the infinity of those from which there is no more reason to choose one than another, trying nothing else?. Leopardi reworked Pascal's thoughts in his famous lyric L'Infinito: "Così tra questa/ immensità s'annega il pensier mio: /e il naufragar m'è dolce in questo mare" (so my mind sinks in this immensity: /and 

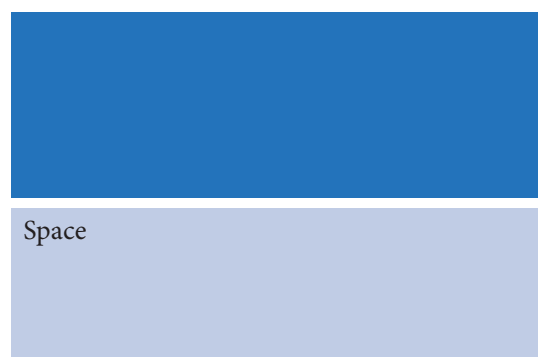

Time

Memory

Data $\begin{aligned} & \text { Things known or assumed as facts, making the basis of } \\ & \text { reasoning (Philosophy). }\end{aligned}$
Information $\quad$ Facts provided or learned about something or someone.
Facts
(i) A piece of information used as evidence or as part of a
(ii) The truth about events as opposed to interpretation (Law).
(iii) The available body of facts or information indicating
(iv) Information given personally, drawn from a document, or in
the form of material objects, tending or used to establish
facts in a legal investigation or admissible as tesimony in court.
(i) The available body of facts or information indicating whether
Evidence
(ii) Information given personally, drawn from a document, or in
the form of material objects, tending or used to establish facts
in a legal investgation or admissible as testimony in court (lab).

Physics

(only what can be measured belongs

to physics)

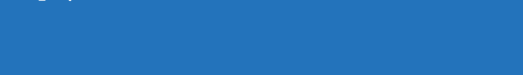

Geometry

Chronometry

The part of a computer in which data or program instructions can be stored for retrieval (discard?)

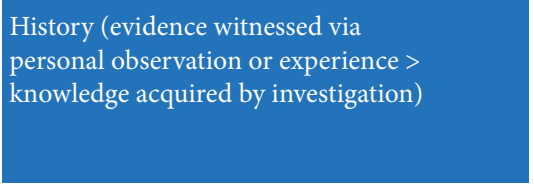

Geography

Chronology

The faculty by which the mind stores and remembers information (memory $>$ selection $>$ eschatology)

Figure 2: The first table (space, time, and memory) is published here for the first time. For the second table (History/Humanities and Physics/Computing), refer to [12]; Table 18.1. In the same paper, Figure 18.1 on page 338 shows the stages a discipline must progress through to become computational: data collection, data management, data visualisation, and model and simulation.

foundering is sweet in such a sea) (see Leopardi, Canti: 106107, where the translator titles incorrectly this idyll Infinity (which in Italian would have been Infinita) instead of The infinite. The poem was first published in [11]:903). We need a metamorphosis, a gesture of civilisation, which-as the poet Giuseppe Ungaretti said to Pier Paolo Pasolini in an interview in 1965- "is an act of human bullying against nature." As the journalist, Jonah Lehrer, explains in How we decide (2009), "rational we are not born, we become. That is, we are born Dionysiac, but to excel we also need to become Apollonian."

The vision rendered here is that neglecting heritage, the treasure of human experience, would leave humanity impoverished and less prepared for the uncertainties and increasing complexities of living together on planet Earth. Human societies have always used their heritage, viz., the inheritable treasure of human experiences (i.e., knowledge and values) accumulated across space and over time, to remain resilient, express cultural identities in their national narratives, and imagine desirable futures by integrating the new with the old (refer to [13]). Nowadays, it seems that the rapid development of society is endangering this spontaneous process of adaptation to change (refer to [14]). Given the increasing pace of technological innovation, many traditional modes of knowledge and value transmission have become obsolete or are at the risk of vanishing. Societies might lose their usual means before they could master new methods to keep their so-far treasured human experiences available in the present and for the future. This loss of cultural heritage would, thus, compromise societal resilience and adaptability to change at a time when they are needed more than ever. To deal with this challenge, public and private synergies in higher education and science and research (humanities complemented by other natural science disciplines) could and should play a major role in providing the vision to prototype, and engineer solutions, with 
imagination (i.e., the faculty of conceiving new ideas and seeing external entities not present to the senses), empathy (i.e., a strong feeling of relationships with others), and $\mathrm{cu}-$ riosity (i.e., a strong desire to know and acquire knowledge by study, experience, or being taught).

Information-communication technology (ICT) has truly opened a new frontier for the advancement of data sharing, and we can agree with Sandra Rendgen that "professional data and information management will be a central cultural tool in the decades to come (refer to [15]:9)." However, ICT alone is not able to support substantial advancement of learning because the exponentially growing volume of digital data is a solution and a problem at the same time. Technology indeed allows us to access more and more information faster and faster from almost everywhere. However, current ICT is unable to retain, structure, and process the amount of digital data produced by society. Moreover, unstructured data per se are of little or negligible value. To become an asset, data need to be filtered, organised, and be machine-readable. This data processing requires considerable natural and human resources that our society may be unable or unwilling to allocate. Thus, due to the risk that many traditional modes of knowledge and value transmission might become obsolete or are at the risk of vanishing soon, our society needs to take the responsibility of deciding the selection criteria of what human knowledge and values to preserve and keep available for the next generation in a digital form.

In nature, genes have their physiological criteria to preserve or discard the information. Heredity-viz., the passing on of physical or mental characteristics genetically from one generation to another to ensure the existence of intelligent life itself-obeys to the laws of function and convenience in relation to the environment in which life spreads and evolves. Human genes are the naturally curated repository of all the experience accumulated by humanity on planet Earth. Human societies added cultural criteria as a complementary trove of valuable knowledge. Cultural heritage-viz., the experiences accrued by human societies that are transmitted by artificial (i.e., human-made) means such as orality, artefacts, and rituals-needs to be curated by humans. As mentioned above, traditional selection criteria are put at risk by today's rapid development of society, globalisation, and digital revolutions. Our society is, thus, urged to decide what to store and what to discard in the digital trove of the human experiences.

There is a cogent need of taking over the responsibility of discussing the best desirable principles for this new digital trove because society needs to reinforce, with more human selection criteria, the algorithms that are already dealing with the selection of valuable data. Today, these algorithms are increasingly written by machines and work mainly on pattern recognition to collect data that are considered worthy of being stored because of free-market rules. In the elaboration of the selection criteria for heritage science, it is essential to add ethics to pattern recognition if we want to avoid the risk of relying only on the authority of the free market whilst de- ciding on the usefulness of the treasure of human experiences (see the report AI and the Ethical Conundrum. How organizations can build ethically robust AI system and gain trust published by the Capgemini Research Institute in September 2020, which demonstrated that one-third of the leaders in charge of AI systems are not competent in understanding the potential biases of their own products. URL: https:/www. capgemini.com/wp-content/uploads/2020/09/AI-and-the-

Ethical-Conundrum-Infographic.pdf). In consideration of the fact that we can only assume what the next generation will need or appreciate in the future, transcultural and intergenerational empathy becomes an essential human value along with the functional and necessary preservation of the environmental characteristics compatible with human life on Earth. For the recent debate on "transculturalism" (an early twentieth-century cultural approach), refer to [16]. For the debate on the intergenerational discussion (in Lacan's psychoanalitic perspective), refer to [17]. For the environmental issues, refer to [18].

These motivations and considerations led the author of this paper to the establishment of the LIBER (Laboratory of Interdisciplinary Bookish and Experiential Research) under the aegis of Michelangelo Pistoletto's Third Paradise at the NTUS School of Art, Design and Media, in January 2019. In Latin, liber means both "book" and "free." Liber/book epitomises the treasure of human experiences as approached by the multidisciplinary domain of heritage science. Liber/ free, as Maestro Pistoletto would say, epitomises the freedom to be responsible and uses all the arts and sciences to reconcile humanity with nature. The Nobel Laureate in Literature Odysseas Elyt is deeply felt this need of reconciliation for the sake of both humanity and individuals: "the lack of harmony between nature and man has led to the lack of harmony between soul and body ... Since life cannot go back, it is men who have to go forward to try to catch it at least by the tail" (refer to [9]:33-34) the English translation is by Andrea Nanetti)." As Helga Nowotny discussed with Maestro Michelangelo Pistoletto and Nobel Laureate in Chemistry Ben Feringa at Nanyang Technological University Singapore on 22 January 2019 (Figure 3), our path forward may both be a Fourth Industrial Revolution along with increased inequality and poverty, driven by power and profit; or it may be a Third Paradise, which marks "the passage to a new level of planetary civilisation, essential to ensure the survival of the human race (refer to http:// terzoparadiso.org/en/what-is accessed on 20 July 2020)," promoting or affording a balanced connection between humanity and nature [19].

The rationale of LIBER is that all the still-available experiences shared by human societies over time and across space are, in principle, essential in coping with the twentyfirst century grand challenges of humanity [20]. We can agree with the philosopher and poet Giacomo Leopardi (1798-1837) that there is stagnation if society is incapable of redesigning its heritage for the future. Leopardi expresses a deep aversion to the present when it loses its connections with the past. He was indeed horrified by the present when it 
is stripped of its connections with the past (refer to [21]). The vision is that, with a clearer understanding of where we came from, we can better understand who we are, where we are now, and what we want to become [22]. Today, heritage science can step up a new gear and provide a crucial contribution to implement this plan and empower human imagination and wisdom. This new heritage science should decode the knowledge and values that humanity embedded in tangible and intangible heritage, encode them in a digital knowledge aggregator (i.e., "knowledge engineering tool that allows its user to assemble information of different kinds from different sources, guided by what the user wants to do with the synthesized whole"), (refer to [23]:159) and make relevant information available to decision-making (where, when, and how it is needed), algorithmically (i.e., using computational procedures).

\section{Discussing Old and New Human Ambitions}

The starting point must be the human condition, which is the most vital and burning issue of all time [24]. In terms of algorithmic thinking, a preliminary ethic consideration needs to be highlighted before starting the computational engine and let AI affirm an automatic form of conduct through ML: humankind, humanity, societies, institutions, and the individual human beings that live in each present may have conflicting expectations and different motivations. Humankind identifies a living species that benefits from the privileges of Darwinian evolution. Humanity, viz., human beings collectively, embraces notions and conceptions not only related to humankind but also to the totality and each of the individual human beings living on Earth in the present. Modernity, with Johann Wolfgang Goethe, believed that exchanging information was an attribute of nature, whereas retaining given information belonged to human culture [25]. Today, this statement must be rephrased because we know that nature retains information in inheritable genes, whereas the human cultural endeavour is the use of information to imagine, design, and implement desired and shared futures wisely. In this social enterprise, research-intensive universities - where the research interests of faculty are shared with students-see an increasingly growing demand for internationalisation and interdisciplinarity (refer to [26]:5557 , and [27]). The vision is that internationalisation and interdisciplinarity processes can increase their sustainability and resilience with the inclusion of transculturalism, local knowledge, and heritage (refer to [22]:88).

At the foundation of this vision stays the fact that individual human beings are all different. As they look different outside, they are different inside. Their minds and consciousnesses show a great deal of variety. There is no normality. Heritage makes no exception. It is valued by each society differently. Unity can only be reached as an agreement to pursue shared projects for the future. Heritage science is all about the future. In this sense, the Renaissance concept of virtus (virtue, in Latin) is still applicable today to frame the discussion on a new science of heritage and empower the design of the future that we dream and desire as both a democratic society and individuals. The Italian
Renaissance word virtude not only identifies a physical and mental value like the ancient Roman virtus but always implies the ability to determine the future, the ability to foresee problems, and to reorganise the present accordingly (refer to [28]:191). In this specific perspective, Niccolò Machiavelli's Discorsi sopra la prima deca di Tito Livio ("Discourses on Livy," ca 1517)-with the thought turned above all to young people and to those of the generations to come-addresses the fact that humans are unable to understand the history, and this is "the cause of the pettiness of modern times compared to the ancients (refer to [29]:182183)." Today, machines are trained to take advantage of history, and they do it as they are instructed. But, how to decide what to teach to machines?

Individuals, institutions, and societies can agree on common goals that they want to achieve for the good of everybody (refer to [30]). For this huge but inevitable task, humans have developed education and laws to mitigate the exploitation of humans perpetrated by humans against other humans. They have the legacy of Mahatma Gandhi to use peaceful means, not violence, to bring about political or social change (refer to [31]:135-161). Therefore, with reference to the principles of right and wrong behaviour, scholars in research institutions and professionals in the industry are morally responsible for what they teach algorithms to do. In academia and the market, Research Integrity and Responsible Conduct policies (environment, experience, and ethos) are still unequal to the task of addressing questions such as "who decides what to teach to algorithms," "how the teaching process is performed" and "how the learning experience is monitored."

This algorithmic processes also need to take into consideration another basic distinction in order to be effective in the domain of heritage science. Knowledge and values perform differently in terms of how they passed on from one generation to the next. Epistemology-the theory of knowledge, especially regarding its methods, validity, and scope, and the distinction between justified belief and opinion-teaches us that data, information, knowledge, and, possibly, wisdom grow with humanity (refer to [23]: 163-164). They can be accumulated, put in latency, and transmitted from one generation to another both naturally, via genes, following the rules of evolution, and artificially through artefacts, education, and experience (refer to [32]). Still, values change across space and over time according to both axiology (i.e., the study of the nature of value and valuation and of the kinds of things that are of aesthetic, epistemic, moral, religious, and sentimental value) and economics (i.e., the appreciation and evaluation of what is worth to be produced, consumed, transferred, and considered wealth). For axiology, refer to [33]. For economics, refer to [34]. Thus, values need to be constantly shared (i.e., possessed in common with others) and continuously confirmed to operate cultural selections in the treasure of human experiences and design the future that we, individual humans and societies, dream and desire.

In practice, we can embrace Umberto Eco's concept of Maximal Encyclopedia, as expressed in the conclusions of his essay From the Tree to the Labyrinth. On the one hand, "if 
cultures survive, one reason is that they have succeeded in reducing the weight of their encyclopaedic baggage by placing so many notions in abeyance, thus guaranteeing their members a sort of vaccination against the Vertigo of the Labyrinth." On the other hand, it "is not the fact that cultures pare down their encyclopaedias (which is, in any case, a physiological phenomenon), but rather that what has been placed in abeyance can always be recovered. For this reason, the regulatory idea of a Maximal Encyclopaedia is a powerful aid to the Advancement of Learning - and having to confront ever and anon the Vertigo of the Labyrinth is often the price we must pay for calling into question the laziest of our ontologies." This Maximal Encyclopaedia is the "truly virtual encyclopaedia" to which every encyclopaedia refers "through a series of cross-references." It is "the sum total of everything that was ever said, or at least of everything that could, in theory, be discovered, to the extent to which it has been expressed through a series of materially identifiable interpretants ... a sort of World Wide Web far richer than the one to which we have access through the Internet (refer to [35]: quotations at pp. 93, 94, 88, and 94 respectively)." Eco's book was originally published as [36]. For a previous version of the same text, see also [37], Ch. 2 (“Dictionary vs. Encyclopedia”):46-86.

In 2016, after what Shawn Graham, Ian Milligan, and Scott Weingart called the "Digital Humanities Moment (refer to [38]: 37-72)," when historians started delving into data management and experimenting with various software to shed new light on their data sets, these authors seemed to find it more challenging to move forward to take full advantage of the fact that computation itself is morphing, as William Brian Arthur would say (refer to [39]:150-151). Indeed, machine learning algorithms, one of the computation's key technologies, underwent a radical change and has now opened new horizons to the automation and speed of pattern recognition as outlined by Pedro Domingos (Figure 4) (see [40]:1-22, Ch. 1. The Machine Learning Revolution). Graham et al. recognised this change as an opportunity for the third wave of computational history because entry barriers to powerful computing and big data have never been lower for historians [38].

As Carpo would say, "the first digital turn changed the way of making history, the second is changing the way of thinking [41]." This second change can initiate an interdisciplinary field of algorithmic research in which, as an example, Natural Language Processing (NLP) and Historical Methods are able to shift from mere automatic pattern recognition to the (semi)automatic mapping of meaningful information (i.e., associate semistructured or unstructured elements of the historical domain with one or more elements of a second set of different entities of the same general type). According to Erik Cambria and Bebo White, to do so, NLP needs to evolve from its current "Syntactics Curve" (i.e., a stage that provides a "Bag-of-Words") to a new "Pragmatics Curve" (providing a "Bag-of-Narratives"), through an intermediate "Semantics Curve" ("Bag-of-Concepts") (refer to [42]:51, Figure 1); here,; Figure 3. This is the proposed pathway to steer a new consilient science capable of propelling a more mature field of both NLP and Digital Humanities into a new Science of Heritage via Computational History $[12,43]$ (in this field, a newopen-access publication by Andrea Nanetti on History and Computers is forthcoming).
In 2015, Domingos stated that "The engine that turns data into knowledge is no longer a black box: you know how the magic happens and what it can and cannot do [40]: 291." In this ambition, technology has both opportunities and limits. In 2009, William Brian Arthur published the results of his research on The Nature of Technology with the clear statement that "more than anything else technology creates our world. It creates our wealth, our economy, our very way of being." However, we still not have a clear understanding of how innovation works. There is no theory of change, and the established hegemony of a technoscientific culture is becoming a significant source of social uncertainty and instability that the human sciences need to address (refer to [44]:38-39). Technology does not work alone. Race, religion, and language are more and more sources of uncertainty. Often, India, China, and Africa are playing critical roles in the global arena. From the perspective of Kuhn's Structure of Scientific Revolutions [45], the global technoscientific civilisation is the newest paradigm shift. In an interview, held on the occasion of the International Congress, "At the dawn of eternity. The first 60 years of The original structure" (Brescia, 2-3 March 2018), the philosopher Emanuele Severino talked about what he defined as "the philosophical subsoil of our time" and its three great inhabitants: Friedrich Nietzsche, Giacomo Leopardi, and Giovanni Gentile (refer to http:// www.raicultura.it).

In 1999, in the Italian Alphabet's episode titled, "In search of poetry," Giuseppe Bertolucci stated that "poetry is ... trying, in that, being able to overcome this state of horrible mechanization to restart (humanity) towards the spontaneity and authenticity of the human person." For Severino, "it will no longer be the capital that uses technology, it will no longer be democracy or Islam or Christianity or nationalisms or states to use the technology, but it will be the technology that uses them." In terms of the amelioration of the human condition, technology does not offer certainty for a better life. However, it appeals to individuals based on promises of a longer and healthier life, a more sustainable economy, a more stable society, a more available education, and so on. Technology asks for the faith that all of this will happen at some point in the future. Academic disciplines, such as the History of Science and Technology (HST) and Science Technology and Society (STS), are studying these topics as crucial factors for a sustainable future [46]. In this pathway, the need for a new science of heritage to treasure human experience becomes more apparent.

The human being can be at the centre of this pathway, a way of achieving what the Greek/Roman stoic concept had defined as $\varphi \imath \lambda \alpha \nu \tau \rho \omega \pi \mathrm{i} \alpha /$ humanitas (refer to [47]:173, and [48]:429-430) and can be translated in today's international English as "empathy." This concept is epitomised by Publius Terentius Afer as Homo sum, humani nihil a me alienum puto/I am human, I consider nothing human to be alien to me in his comedy Heautontimorumenos based on Menander's 'E $\alpha v \tau$ òv $\tau \iota \mu \omega \rho o u ́ \mu \varepsilon \nu o \varsigma$ (The Self-Tormentor refer to Publii Terentii Afri [ca 190-185-159 BCE], Heautontimorumenos, Act I, Scene 1, Line 25/77) and by Marcus Tullius Cicero's studia humanitatis ac litterarum in his oration in defence of 


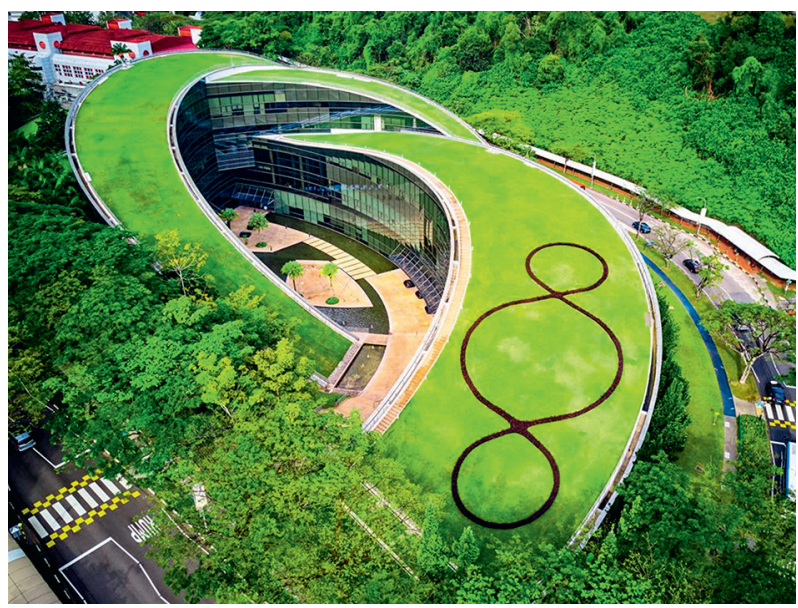

Figure 3: Michelangelo Pistoletto's Third Paradise. Art installation. Nanyang Technological University Singapore, School of Art, Design and Media. The plant used in the installation, Alternanthera sessilis' "Red," is not present in nature but grows only in greenhouses. We are the ones who keep this "artifice" alive, which is a way to experience the beauty of being free to choose the ethics of responsibility and commitment in life. This image was licensed under a Creative Commons Attribution-NonCommercial 4.0 International License (CC BYNC 4.0) by Nanyang Technological University Singapore and Fondazione Pistoletto in 2019 [1].

the poet Archia (Etenim omnes artes, quae ad humanitatem pertinent, habent quoddam commune vinclum et quasi cognatione quadam inter se continentur/In truth, all the arts which concern the civilising and humanising of men [better read: all the sciences which relate to the human nature and condition], have some link which binds them together, and are, as it were, connected by some relationship to one another) (see Marci Tullii Ciceronis [106-43 BCE], Pro Archia peoeta, translated from Latin to English by C. D. Yonge, London: Henry G. Bohn, 1856; in particular, and the quotes, 2 and II.3, respectively).

In the diverse philosophical and political identities of the Renaissance cultural movement known as Humanism, the treaties on pedagogy have been often seen as the common ground for the education of the ideal member of civil society. This literary subgenre was introduced by Pier Paolo Vergerio's seminal work, De ingenuis moribus et liberalibus studiis ("on the Manners of a Gentleman and Liberal Studies") (see [49]). In [49], which was completed in Padua in 1402-1403 and soon followed by other humanists, the studia humanitatis or studia humaniora (the study of the humanae litterae, human studies, or the studies befitting a human being) ([50]:185), who is referring to [51]:365, were meant neither to train people for professional development nor to initiate youth to the contemplative life. Rather, the reading and discussion of human endeavours in grammar, rhetoric, poetry, history, and moral philosophy "aimed to shape the soul, to form the moral and aesthetic sense, to create citizens ready for the vita activa [active life] (see [52]:427);" "in the attempt to educate both princes and private citizens to serve the needs of the state. . . a preparation for a life of virtue (see [50]: 28)."

The values of this paideia/ $\pi \alpha \iota \delta$ \&i $\alpha$ (education) were of the essence in the culture of Renaissance. In English, see $[53,54])$. However, in these two books, it is difficult to see any consistent advancement of learning when compared to [55], who provided a still-unrivalled contribution to the appreciation of the fundamental reasons of radical human renewal that ensured the successful spread of humanistic culture in Europe (see [56]:482-490). In particular, we can refer to the three qualities of utilitas/usefulness, namely, honor/honour (i.e., the quality of doing what is morally right), decus/distinction (i.e., the quality of being excellent), and commodum/convenience (i.e., the quality of being suitable to serve the needs of the society), as they were elaborated by both the Church and the humanistic culture of the time (refer to [57-59]). Today, in the aftermath of the WASP-Gentlemen's evident inadequacy to overcome its intrinsic nature, $\varphi \iota \lambda \alpha \nu \tau \rho \omega \pi i \alpha /$ humanitas/empathy seems to be the key to understand the other and can serve contemporary globalised youth to connect as human beings beyond race, religion, and culture.

In Europe, an example of this philosophical and practical understanding of empathy, as social catena (human chain), the ultimate human quality and hope, can be found in Giacomo Leopardi's poem, Broom (La Ginestra, v. 149) composed at Villa Ferrighi (Torre del Greco) in 1836 (see [60]:286-309). The poem was first published by A. Ranieri (refer to [61]:119-127). This thought results from a vast philosophical erudition that ranges between eras and disciplines through ancient and modern languages, encompassing the heritage that was available in Europe at his time. After taking stock of what science had discovered on the materialist structure of reality, he asserted the groundlessness of human values and the total indifference of nature towards the destiny of mankind. Leopardi indeed anticipated Nietzsche in overturning the religious and humanistic values of the Christian order of the world and setting the human condition in a new framework (refer to [21]).

Franz Kafka, in a letter to Oskar Pollak dated 9 November 1903, expressed similar hopes and needs when he 
wrote: “... Verlassen sind wir doch wie verirrte Kinder im Walde. Wenn Du vor mir stehst und mich ansiehst, was weißt Du von den Schmerzen, die in mir sind und was weiß ich von den Deinen. Und wenn ich mich vor Dir niederwerfen würde und weinen und erzählen, was wüßtest $\mathrm{Du}$ von mir mehr als von der Hölle, wenn Dir jemand erzählt, sie ist heiß und fürchterlich. Schon darum sollten wir Menschen vor einander so ehrfürchtig, so nachdenklich, so liebend stehen wie vor dem Eingang zur Hölle (we are abandoned like lost children in the forest. When you stand in front of me and look at me, what do you know about the pains that are in me and what do I know about yours. And if I prostrate myself in front of you and cry and tell you, what would you know more about me than about hell, if someone told you that it was hot and terrible. For that reason alone, we humans should stand before one another so reverently, so thoughtfully, as lovingly as in front of the entrance to hell) (see [62])."

Within this cultural context, heritage science can have the vision to the following:

(1) Develop transcultural advancement of understanding the human condition with a "glocal" approach (i.e., for global futures with local heritage). The neologism glocal was apparently coined by Manfred Lange who, in his work for the May 1990 Global Change Exhibition, sought to capture the complex interplay between the local, the regional, and the world-wide" as reported in [63]: 80 .

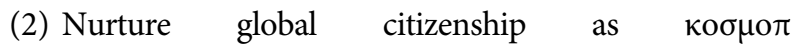

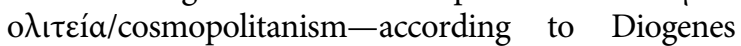
Läertius' [180-240 CE] Vitae Philosophorum (Bío kai

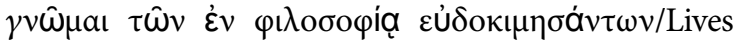
and Opinions of Eminent Philosophers), when the preSocratic philosopher Diogenes of Sinope (or Diogenes the Cynic [circa 412-323 BCE]) was asked where he came from, "he answered: 'I am a citizen of the cosmos'

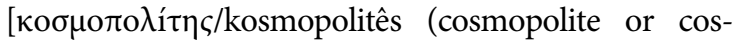
mopolitan)]" (VI, 63). This can be done in the real world, which is l'aiuola che ci fa tanto feroci (Dante Alighieri, Paradiso, XXII, 151: The little threshing-floor which makes us so fierce) [64], with the ethics of "freedom as a generator of responsibility" (refer to [65]: 64-73). For the evolution of the relationship between freedom and responsibility from World War II to today, see [25].

(3) Eventually, educate the next generation of human scientists and decision-makers who are called upon to take up the grand challenges of humanity in the 21st century [66], for life on planet Earth, and for what may lie beyond [67]. See, among others, the 17 Sustainable Development Goals that the United Nations are targeting to be achieved by 2030 (https:// www.un.org/sustainabledevelopment/sustainabledevelopment-goals), the $\mathrm{BBC}$ list published by Bryan Lufkin on http://www.bbc.com/future/story/ 20170331-50-grand-challenges-for-the-21st-century (accessed on 13 February 2021).
In nurturing this vision for a new science of heritage, the inspiration comes from Ars Generalis Ultima (The Ultimate General Art), aka Ars Magna (The Great Art), by Ramon Llull (1232-1316), who introduced the encyclopaedic ideal, the use of mathematics, and visual mnemotechnics to pioneer what is now called the theory of computation (refer to [68]). A powerful thinking tool can be found in the Seven Circumstances ("Who, What, Where, When, Why, How, and By What Means") used by Aristotle to examine human actions (refer to Aristotle, Nicomachean Ethics, 1111a3-8), more recently propagated by Rudyard Kipling (surprisingly without "by what means" and as such used in the curricula of the US schools of journalism). This method was also applied by Giambattista Vico, who, at the dawn of Enlightenment, in his magnum opus, the Scienza Nuova (1725, New Science [69]), argued that a new grammar was needed to select and define the essential components (facts) and to validate these facts based on evidence by answering the questions "Who," "What," "Where," and "When." With this grammar, scholars can "come to terms" to structure a new language. Afterwards, logic can be applied to process data. Facts can be better understood and related to each other after removing contradictions, that is, after answering the question, "Why" (e.g., in a cause-and-effect relationship). To complete this "trivium metaphor," (McLuhan's Global Village can be seen as an epigone of this tradition; refer to [70]) the rhetoric to be put in place to produce wisdom needs to answer the questions, "How" and "By What Means," based on evidence (i.e., taking into consideration only facts validated in the grammar with a full demonstration of "Who," "What," "Where," and "When"). Furthermore, this trivium teaches us that working on relationships without having verified its agents is like putting logic before grammar. It can easily result in conclusions without foundations. Sometimes, this procedure is used to intentionally manipulate facts and produce misinformation.

\section{Exploring a New Methodology for a New Science of Heritage}

After having discussed why, what, who, where, when, and how, let us discuss the systematic means, the methods that can be used by this new science of heritage. To feed AI and machine learning in facilitating human thinking and finding solutions to complex problems, Andrea Nanetti, at the LIBER Lab, in the NTU School of Art, Design and Media, proposes to students and faculty a tetrahedron of research methodologies (artistic, design, and academic) grounded in art, culture, and heritage (see Figure 5). Here, this openness to multidisciplinary approaches to knowledge is seen as a first step, not only towards the implementation of holistic methodologies in general but also for designing and writing algorithms that can be interdisciplinary (i.e., the synthesis of two or more disciplines, establishing a new level of discourse and integration of knowledge). According to Julie Thompson Klein, interdisciplinary initiatives are characterised by the form or structure they take (e.g., team work), their motivation (e.g., to serve societal needs), how the disciplines interrelate (e.g., physics can be taught in the service of history), or by their integration level (e.g., from cross-reference to oneness). 


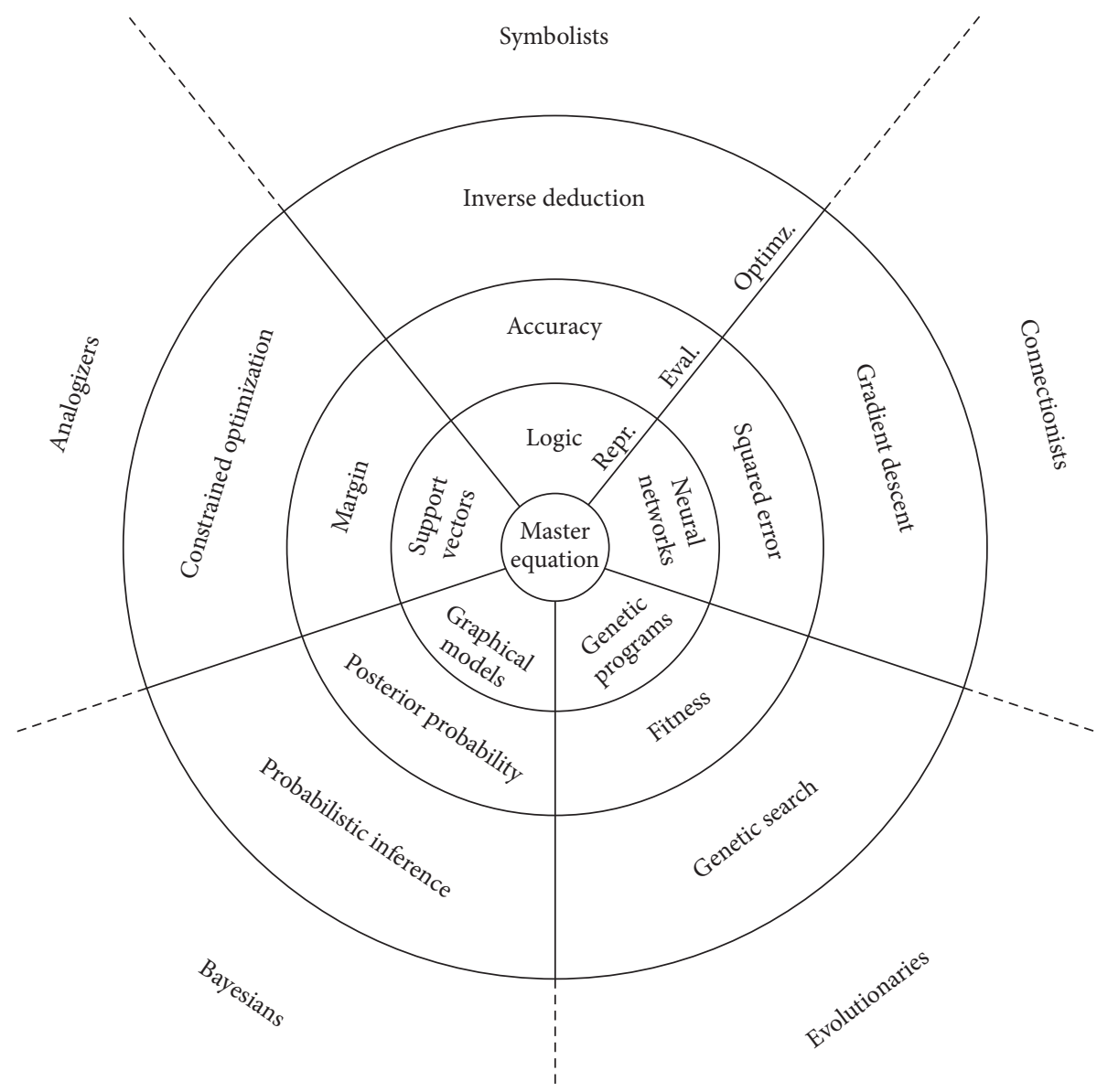

Figure 4: Pedro Domingos' diagram (p. 240) of the "five tribes of machine learning and their master algorithms: symbolists and inverse deduction; connectionists and backpropagation; evolutionaries (read evolutionists) and genetic algorithms; Bayesians and probabilistic inference; and analogizers (read analogists) and support vector machines" (p. 291).

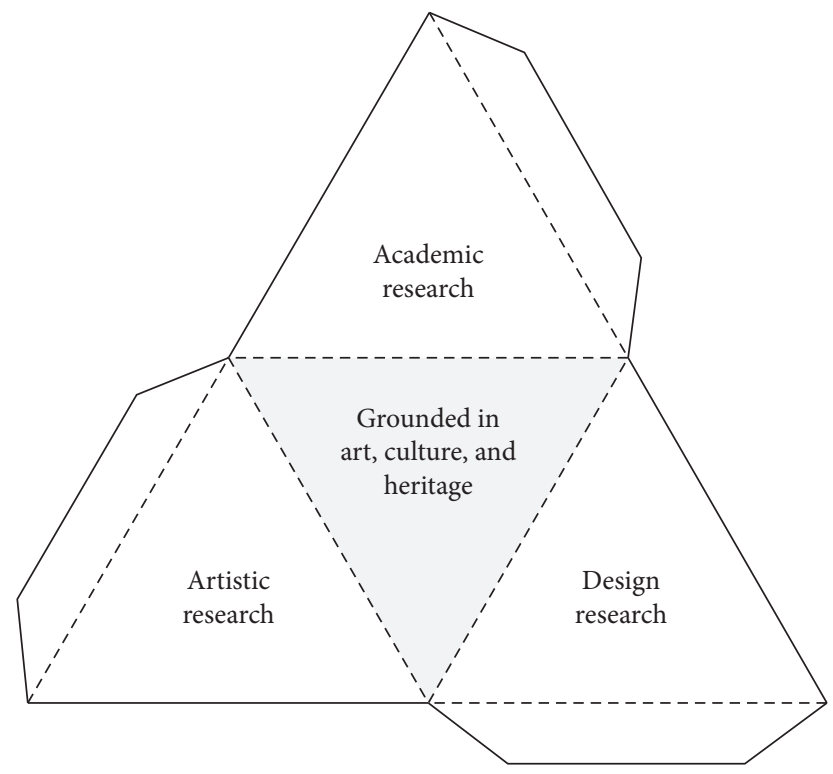

FIGURE 5: Cut-and-tape tetrahedron of research approaches (artistic, design, and academic) grounded in art, culture, and heritage to raise questions and prescribe transdisciplinary solutions to complex problems. This work was licensed under a Creative Commons AttributionNonCommercial 4.0 International License (CC BY-NC 4.0) by Andrea Nanetti in 2017. 


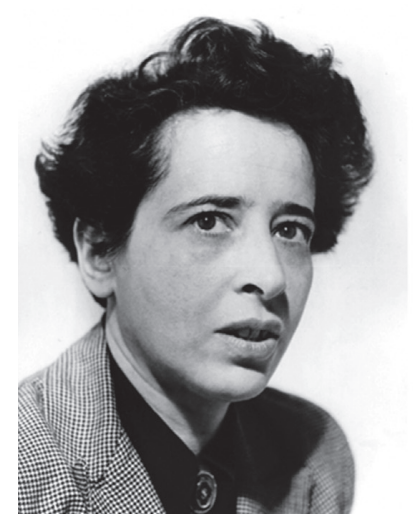
Hannah Arendt Power: the capacity or ability to
$(1906-1975)$, portrait (1941) by photographer Fred Stein. Digital Image from WorldHistoria. direct or influence the behaviour of others or the course of events

Violence: the unlawful exercise of physical force or intimidation by the exhibition of such force

Strength: the influence
or power possessed by a person,
organization, or country

Figure 6: "Hannah Arendt is preeminently the theorist of beginnings. All her books are the tales of the unexpected ..., and reflections on the human capacity to start something new pervade her thinking... Often the way she sheds light into neglected corners of experience is by making new distinctions, many of them threefold as if conventional dichotomies were too constricting for her intellectual imagination. The Human Condition [first edition 1958] is crammed with distinctions: between labor, work, and action; between power, violence, and strength; between the Earth and the world" (see [24]).

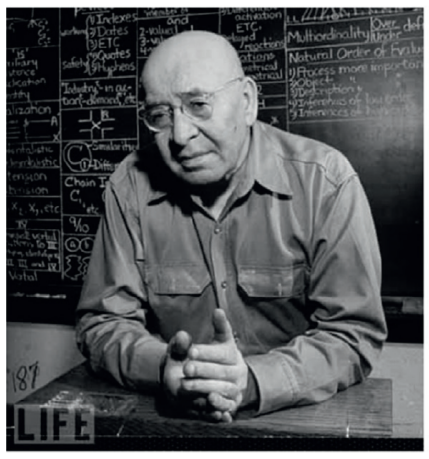

Rejection of the principle of identity and the recognition of so-called "multiordinal terms." The principle of identity is structurally impossible, and orientation based on it is "delusional" and "cannot lead to adjustment and sanity." "The mechanism of identification" should be "eliminated by special training" which is "therapeutic in effect." The author proposes a simple structural diagram, "structural differential," with which "the general verbal rejection of 'identity' is translated into ordering, which becomes a visual, kinesthetic, neuro-psychological method to train in non-identity or discrimination, and so to eliminate the always dangerous identifications, which play such an important part in all maladjustments."

ursmmumnsi.ipg

Refer to https://psycnet.apa.org/record/1934-01910-000

Figure 7: Visual, kinaesthetic, neuropsychological method. Introduced by Alfred Korzybski to train in nonidentity. In his book entitled "Science and sanity. An Introduction to Non-Aristotelian Systems and General Semantics" [71], Korzybski states and demonstrates that Aristotelian systems are inadequate to face the challenges of our society. Socrates (469-399 BCE), his student Plato (427-347 BCE), and Plato's student Aristotle (384-322 BCE) formulated the complete system of knowledge and education of their time, which was perpetrated until today. Aristotle "aimed to formulate a general method for "all" scientific work." He was so comprehensive that, so far, it has been changed only field by field. Korzybski uses the history of mathematics to highlight how non-Aristotelian methods were needed and developed for the advancement of learning in this specific field (Introduction to the second edition, 1941, pp. xlix-l). However, "no methodological general theory based on the new developments of life and science had been formulated until general semantics and a general, extensional, teachable, and communicable, non-Aristotelian system was produced. The main difficulties ahead are neurosemantic and neurolinguistic because for more than 2,000 years, our nervous systems have been canalized in the inadequate, Aristotelian orientations, which are reflected even in the structure of the language we habitually us" (ibidem, pp. xlix-l).

This contrasts with multidisciplinary, which is a process for providing a juxtaposition of disciplines that is additive, not integrative. Transdisciplinary approaches provide holistic schemes that subordinate disciplines, looking at the dynamics of whole systems, such as structuralism or Marxism. Crossdisciplinary methods refer to examples from one discipline that can be used in others. For these distinctions, refer to [26]: 55. The rationale is that different academic disciplines have different assumptions and understandings of the same things, and all these different approaches need to be taught to machines in the perspective of a new science of heritage. As an example, we can highlight the ways of recording space-time in physics and history or the different understanding of words, such as data, information, facts, evidence, event, in history, and computing (Figure 2).

The proposal is to support the axiomatic formalisation of heritage as a new science able to build semantic taxonomies and train ML algorithms through the application of four key methods: (1) the triplets (threefold distinctions) applied by Hannah Arendt to start thinking about the human condition (Figure 6); (2) the visual, kinaesthetic, neuropsychological method introduced by Alfred Korzybski to train in nonidentity (Figure 7); (3) the D.A.N.C.I.N.G. method (Definition, Assumption, Notion, Conception, Interpretation, Narrative, Gamut) to understand complex words (Figure 8); and, last but not least, 


\section{D.A.N.C.I.N.G.}

Definition
Assumption
Notion
Conception
Interpretation
Narrative
Gamut

Definition (定义)

A statement of the exact meaning of a word, especially in a dictionary, which aggregates the use of the term in a specific language (e.g., dictionary mashup).

Assumption (臆测)

A statement accepted as true without proof in a disciplinary context seen as a pre-requisite for interdisciplinary research. "Disciplinary researchers absorb a host of disciplinary assumptions in the course of their education: research. "Disciplinary researchers absorb a host of disciplinary assumptions in the course of their education:
epistemological, ethical, ideological, theoretical, and methodological. They may often not be conscious of these assumptions. Yet they interpret what others say through the lens of these assumptions" (Szostak, Gnoli, \& López-Huertas, 2016, p. 58)

Notion (理解)

A conception of or factual belief about something, especially in an encyclopedia that aggregates the knowledge of a cultural group or a disciplinary field (Eco 2014, pp. 3 to 94).

Conception (概念)

An abstract belief justified as true; a certain understanding as opposed to opinion; an idea presented as a plan (but not yet achieved as factual belief), especially conceived/born in a disciplinary silo (Koselleck, 2002). Interpretation (解释/翻译)

The action of explaining the meaning of something (i.e., a translation of a sign into another system of signs according to the volume 4 of the collected papers by Charles S. Peirce (see Hartshorne \& Weiss, 1933, p. 127), who apparently uses 'translation' as a synecdoche, i.e., pars pro toto, for 'interpretation').

Narrative (叙述/故事)

A spoken or written account of connected events; a story. Mid 17th century: from Latin narrat: 'related, told', from the verb narrare and from gnarus 'knowing' (Altman, 2008).

Gamut (范围)

The complete range or scope of something (scale of musical notes).

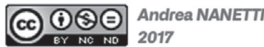

Figure 8: The D.A.N.C.I.N.G. method is a systematic procedure for the understanding of words that connote the complexity of human things, human nature, and the human condition (e.g., beauty, knowledge, science, art, technology, truth, justice, and love). The dancing method was created by Andrea Nanetti for the digital advancement of learning in 2017. Since then, this method has been successfully introduced by Nanetti in research and teaching at Nanyang Technological University, Singapore, and in master classes and keynotes, internationally, to provide a quick and robust multidisciplinary understanding of complex words whilst starting a new enquiry or simply addressing a topic to an audience. This method has been proved to be handy to guide humans and can be transferred to algorithms in the accomplishment of the whole gamut of different ways of seeing fundamental words. The Dancing Method was licensed under a Creative Commons Attribution-NonCommercial 4.0 International License (CC BY-NC 4.0) by Andrea Nanetti in 2017 [72-74].

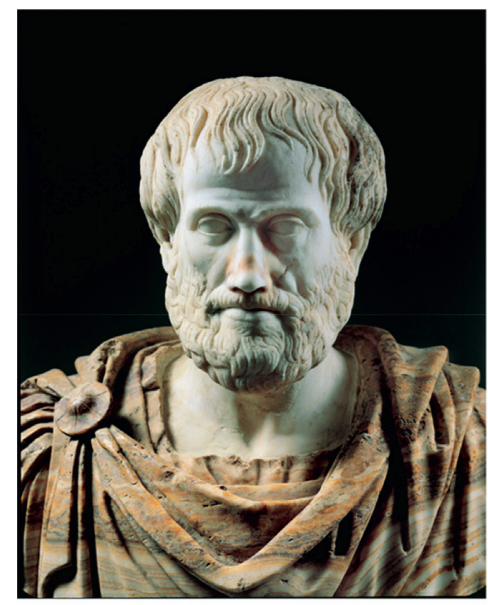

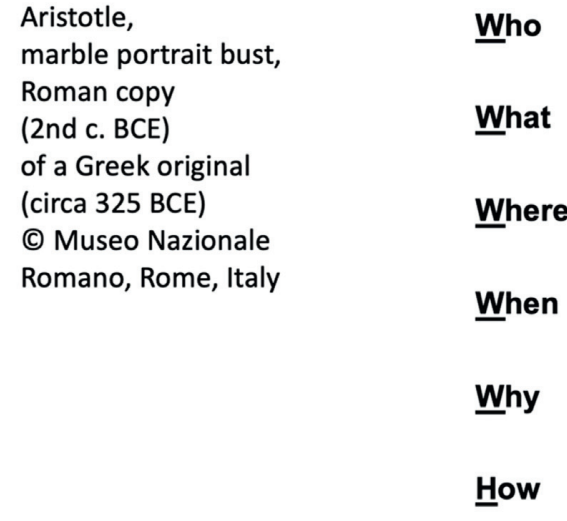

by What means

Figure 9: The seven circumstances are relevant to examine human actions. The earliest evidence of the use of this ur-method is in Aristotle, Nicomachean Ethics, 1111a, 3-8.

(4) the seven circumstances used by Aristotle to examine human actions (who, what, where, when, by what means, why, and how) (Figure 9).

\section{Conclusions}

In conclusion, the mission for heritage science should be to answer the question: what kind of heritage should our society take care of and by what means can it be safeguarded and transmitted? In addition, how could we leverage the increasing prevalence of technological developments to highlight and explain cultural and societal changes and illustrate potential future scenarios and visionaries, transmitting accumulated knowledge and discussing values (i.e., what is important in life) that we want to share? These are the key questions that need to be answered. The foundation of a new formal science of heritage needs the consolidation of a grammar that can be used worldwide and understood in different cultural contexts. This science could then showcase success stories, where cultural heritage has been convincingly employed to revitalise a community beset by natural or man-made disasters. It could also teach society to learn from stories of its failures, where communities endowed with rich cultural heritage should have been capable of coping with crises but made a series of poor decisions that lead to significant loses in their identities, cohesiveness, and heritage (Figure 1). 


\section{Data Availability}

The data used to support the finding of the study are included within the article.

\section{Conflicts of Interest}

The author declares that there are no conflicts of interest.

\section{Acknowledgments}

This article, which is both a position and a review paper, has been written in the campus of Nanyang Technological University, Singapore, during the COVID-19 circuitbreaker, after office hours, in 2020. The thoughts and ideas presented in this work were defined and discussed earlier: firstly, with several colleagues, on different occasions, during the Forum "Next Generation, Please!" organised in the framework of the UNESCO Creative Cities Network by Cittadellarte-Fondazione Pistoletto (Italy, Biella, 23 May 2019); secondly, when I was a visiting Scholar at Università di Venezia Ca' Foscari (from 15 June to 15 August 2019); and, thirdly, on the occasion of a lecture on Big Data and the Advancement of Learning. For a Sustainable and Open Knowledge Society, which I gave for Department of Network and Data Science and Provost's Office at Central European University on 5 March 2020, which was my last overseas travel before the confining to my dwelling because of the spread of COVID-19. To all these institutions and their people goes my deepest gratitude for their generosity and the spirit of academic freedom that ultimately inspired this work.

\section{References}

[1] M. Pistoletto, “The third paradise,” 2020, http://terzoparadiso. org/en/what-is.

[2] G. Bast, “"DANCING over ideas of research": Eine zukunftsorientierte kooperation mit Singapur im kunst- und bildungsbereich," in Austria Kultur International Jahrbuch der Österreichischen Auslandskultur, pp. 65-67, Bundesministerium für Europa, Integration und Äußeres - Sektion für Kulturelle Auslandsbeziehungen, Vienna, Austria, 2018.

[3] R. Comunian, A. Rickmers, and A. Nanetti, "The creative economy is dead-long live creative-social economies," Social Enterprise Journal, vol. 16, 2020.

[4] C. P. Snow, The Two Cultures and the Scientific Revolution: The Rede Lecture 1959, Cambridge University Press, Cambridge, UK, 1962.

[5] E. O. Wilson, Sociobiology: The New Synthesis-25th Anniversary, Harvard College, Cambridge, MA, USA, 2000.

[6] E. O. Wilson, Biological Diversity: The Oldest Human Heritage, University of the State of New York, State Education Dept., New York State Museum, Albany, NY, USA, 1999.

[7] E. O. Wilson, Consilience the Unity of Knowledge, Westminster: Knopf Doubleday Publishing Group, 1st edition, 2014.

[8] E. G. Slingerland and M. Collard, Creating Consilience: Integrating the Sciences and the Humanities, Oxford University Press, Oxford, UK, 2012.

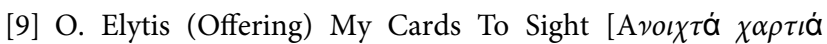
( $\sigma \nu \lambda \lambda o \gamma \eta \dot{n} \kappa \varepsilon \mu \varepsilon \dot{\varepsilon} \nu \nu)$ ], Athens: Asterias Editions, 1973..

[10] B. Pascal, Les Pensées, E. P. Dutton \& Co., Inc., New York, NY, USA, 1958, https://ebooks.adelaide.edu.au/p/pascal/blaise/ p27pe/complete.html, 2nd edition.

[11] G. Leopardi, "L'infinito," Il Nuovo Ricoglitore, Ossia Inc., Bellevue, WA, USA, 1825.

[12] A. Nanetti and S. A. Cheong, "Computational history: from big data to big simulations," in Big Data in Computational Social Science and Humanities, S.-H. Chen, Ed., pp. 337-363, Springer International Publishing AG, Cham, Switzerland, 2018.

[13] B. Kahane, "La dimension identitaire de l'information à l'ère des algorithmes et de l'intelligence artificielle," in La Transmission en Question(s), pp. 633-656, Éditions in PRESS, Paris, France, 2020.

[14] T. Moreau, "Héritage, transfert, mémoire. Ce qui se reçoit, s'élabore, se transmet-avec qui?" in La Transmission en Question(s), pp. 361-370, Éditions in Press, Paris, France, 2020.

[15] S. Rendgen and J. Wiedemann, Information Graphics, Tashen, Cologne, Germany, 2013.

[16] M. Herren, M. Rüesch, and C. Sibille, Transcultural History: Theories, Methods, Sources, Springer-Verlag, Berlin, Germany, 2012.

[17] M. Recalcati, Il Complesso di Telemaco. Genitori e Figli dopo il Tramonto del Padre, Feltrinelli Editore, Milano, Italy, 2013.

[18] https://www.unenvironment.org United Nations Environment Programme.

[19] A. Nanetti, The Third Paradise at NTU Singapore in Michelangelo Pistoletto, Between Obverse and Reverse, [Catalogue of the Exhibition, Partners and Mucciaccia, Singapore, 19 Jan-27 July 2019], Carlo Cambi Editore, pp. 70-74, Rome, Italy, 2019.

[20] A. Nanetti, "Expanding the thinkable future beyond inherited pasts and visible presents," in Proceedings of the 2019 Gingko Meeting, Vienna, Austria, 2019.

[21] R. P. Harrison, "La magia di leopardi," 2014, https://www. 451online.it/la-magia-di-leopardi/.

[22] A. Nanetti and A. Simpson, "Sharing our heritage to shape our future. How effective are multi-user sharing platforms in supporting collaborative visioning for the future, and why is heritage centre-stage?" in Proceedings of the 5th International Conference on Social Media Technologies, Communication, and Informatics, pp. 82-90, Wilmington, DE: IARIA XPS Press, Barcelona, Spain, November 2015.

[23] N. Andrea, A. Cattaneo, S. Ann Cheong, and C.-Y. Lin, "Maps as knowledge aggregators: from renaissance Italy Fra Mauro to web search engines," The Cartographic Journal, pp. 159167, 2015.

[24] H. Arendt, The Human Condition, The University of Chicago Press, Chicago, IL, USA, 2nd edition, 1958.

[25] A. Gailus, "Forms of life: nature, culture, and art in Goethe's Wilhelm Meister's apprenticeship," The Germanic Review: Literature, Culture, Theory, vol. 87, no. 2, pp. 138-174, 2012.

[26] J. T. Klein, Interdisciplinarity: History, Theory and Practice, Wayne State University Press, Detroit, MI, USA, 1990.

[27] Deborah DeZure, What is Interdisciplinary Learning? on http://departments.knox.edu/facdev/archives/POD_packets/ Packet1/Interdisciplinary\%20Teach\%23EC3.htm, 2020.

[28] N. Gardini, Rinascere. Storie e Maestri di un'Idea Italiana, Garzanti, Milano, Italy, 2019.

[29] M. Viroli, Il Sorriso di Niccolò. Storia di Machiavelli, Editori Laterza, Bari, Italy, 1998. 
[30] M. Ignatieff, The Ordinary Virtues: Moral Order in a Divided World, Harvard University Press, Cambridge, MA, USA, 2017.

[31] G. Pontara, L'Antibarbarie. La Concezione Etico-Politica di Gandhi e il XXI Secolo, Edizioni Gruppo Abele, Torino, Italy, 2nd edition, 2019.

[32] S. Sim and B. Seet, Eds., The Chronicles of Evolution, Wildtype Books, Singapore, 2018.

[33] S. L. Hart, "Axiology-theory of values," Philosophy and Phenomenological Research, vol. 32, no. 1, pp. 29-41, 1971.

[34] J. Reardon, M. A. C. Madi, and M. Scott Cato, "Economic value," in Introducing a New Economics: Pluralist, Sustainable and Progressive, pp. 153-166, Pluto Press, London, UK, 2018.

[35] U. Eco, From the Tree to the Labyrinth. Historical Studies on the Sign and Interpretation, Harvard University Press, Cambridge, MA, USA, 2014.

[36] U. Eco, Dall'Albero al Labirinto. Studi Storici sul Segno e l'Interpretazione, Bompiani, Milano, Italy, 2007.

[37] U. Eco, Semiotics and the Philosophy of Language, Indiana University Press, Bloomimgton, IN, USA, 1983.

[38] S. Graham, I. Milligan, and W. Scott, Eds., The Historian's Macroscope, Imperial College Press, London, UK, 2016.

[39] W. B. Arthur, The Nature of Technology. What it is and How it Evolves, Free Press, New York, NY, USA, 2009.

[40] P. Domingos, The Master Algorithm: How the Quest for the Ultimate Learning Machine Will Remake Our World, Basic Books, New York, NY, USA, 2015.

[41] M. Carpo, The Second Digital Turn: Design beyond Intelligence, MIT Press, Cambridge, MA, USA, 2017.

[42] E. Cambria and B. White, "Jumping NLP curves: a review of natural language processing research," IEEE Computational Intelligence Magazine, vol. 9, no. 2, pp. 48-57, 2014.

[43] A. Nanetti, "Overcoming linguistic obstacles and cultural barriers in the transcultural (re)-reading of primary sources and secondary literature for afro-Eurasian pre-modern history (1205-1533)," in Order/Disorder in Asia: Historical Perspectives, R. Mukherjee, Ed., The Asiatic Society, Kolkata, India, 2021.

[44] L. Tomasin, L'Impronta Digitale. Cultura Umanistica e Tecnologia, Carocci Editore, Rome, Italy, 2017.

[45] T. S. Kuhn, The Structure of Scientific Revolutions, University of Chicago Press, Chicago, IL, USA, 4th edition, 2012.

[46] W. E. Bijker, T. P. Hughes, T. J. Pinch, and D. G. Douglas, The Social Construction of Technological Systems: New Directions in the Sociology and History of Technology, MIT Press, Cambridge, MA, USA, 2012.

[47] C. Higgins, "Humanism, cosmopolitanism, and the ethics of translation," Educational Theory, vol. 64, no. 5, pp. 429-437, 2014.

[48] J. E. G. Zetzel, "Cicero and the scipionic circle," Harvard Studies in Classical Philology, vol. 76, pp. 173-179, 1972.

[49] D. Robey, "Humanism and education in the early quattrocento: the de ingenuis moribus of P. P. Vergerio [1370-1444]," Bibliothèque d'Humanisme et Renaissance, vol. 42, pp. 27-58, 1980.

[50] B. G. Kohl, "The changing concept of the studia humanitatis in the early renaissance," Renaissance Studies, vol. 6, no. 2, pp. 185-209, 1992.

[51] P. O. Kristeller, "Humanism and scholasticism in the Italian renaissance," Byzantion, vol. 17, pp. 346-374, 1944.

[52] S. Ferente, "La civiltà dei maestri," in Atlante Della Letteratura Italiana, vol. 1, pp. 427-432, Einaudi, Torino, Italy, 2010.

[53] R. Black, Humanism and Education in Medieval and Renaissance Italy. Tradition and Innovation in Latin Schools from the Twelfth to the Fifteenth Century, Cambridge University Press, Cambridge, UK, 2001.

[54] P. F. Grendler, Schooling in Renaissance Italy: Literacy and Learning, 1300-1600, The Johns Hopkins University Press, Baltimore, MD, USA, 1989.

[55] E. Garin, Il Pensiero Pedagogico dell'Umanesimo, Coedizioni Giuntine Sansoni, Florence, Italy, 1958.

[56] S. Zanardi, "La pedagogia dell'Umanesimo nell'interpretazione di Eugenio Garin," in Dimensioni dell'Educare e il Gusto della Scoperta nella Ricerca. Studi in Memoria di Duilio Gasparini, pp. 482-490, Armando Editore, Rome, Italy, 2011.

[57] C. Frova, "Processi formativi istituzionalizzati nelle società comunali e signorili italiane: una politica scolastica?" in Culture et Idéologie dans la Génèse de l'État Moderne, pp. 117-131, École Française de Rome, Rome, Italy, 1985.

[58] S. Marcucci, La Scuola tra XIII e XV Secolo. Figure Esemplari di Maestri, Istituti Editoriali e Poligrafici Internazionali, Pisa, Italy, 2002.

[59] P. Rosso, "La scuola nelle corti tardomedievali dell'Italia nordoccidentale: circolazione di maestri e di modelli," Mélanges de l'École Française de Rome-Moyen Âge, vol. 127, 2015.

[60] G. Leopardi, Canti, Poems Bilingual Edition Translated and Annotated by Jonathan Galassi, Farrar, Straus, and Giroux, New York, NY, USA, 2010.

[61] A. Ranieri, Ed., Opere di Giacomo Leopardi, Felice Le Monnier, Florence, Italy, 1845.

[62] F. Kafka, Briefe 1902-1924, S. Fischer, Frankfurt, Germany, 1958.

[63] J. Schnapp, "Animating the archive," in Animated Archive, pp. 72-80, Electa, Milano, Italy, 2013.

[64] The English translation is by Courtney Langdon, Cambridge: Harvard University Press, 1921.

[65] M. Pistoletto, The Third Paradise, Marsilio Editori, Venice, Italy, 2010.

[66] J. W. Vasbinder, B. Gulyás, and J. Y. H. Sim, Grand Challenges for Science in the 21st Century, World Scientific, Singapore, 2018.

[67] C. J. Preston, “The synthetic age," Outstanding Evolution, Resurrecting Species, and Reengineering Our World, The MIT Press, Cambridge, MA, USA, 2018.

[68] A. Bonner, The Art and Logic of Ramon Llull. A User's Guide, Brill Academic Publishers, Leiden, Netherlands, 2008.

[69] L. Pompa, [Giambattista Vico] the First New Science, Cambridge University Press, Cambridge, UK, 2002.

[70] M. McLuhan, The Gutenberg Galaxy: The Making of Typographic Man, Routledge and Kegan Paul, London, UK, 1962.

[71] A. Korzybski, Science and Sanity. An Introduction to NonAristotelian Systems and General Semantics, International Non-Aristotelian Library Pub. Co., New York, NY, USA, 5th edition, 1994.

[72] R. Altman, A Theory of Narrative, Columbia University Press, New York, NY, USA, 2008.

[73] C. Hartshorne and P. Weiss, Eds., The Collected Papers of Charles Sanders Peirce, Harvard University Press, Vol. 4, Cambridge, MA, USA, 1933.

[74] R. Szostak, C. Gnoli, and M. López-Huertas, Interdisciplinary Knowledge Organisation, Springer, Berlin, Germany, 2016. 